\title{
TRADITIONAL AND ORGANIC PRODUCTS ON EXAMPLE OF "FIGA" FAMILY-OWNED ORGANIC FARM FROM PODKARPACKIE PROVINCE
}

\begin{abstract}
Traditional and organic products are distinguishing marks of a region, reflect a long-established tradition and cultural heritage, as well as show potential for the growth of local businesses. This paper aims to present and demonstrate how traditional and organic products are promoted on the example of products originating from Podkarpackie Province and to indicate barriers, challenges that must be overcome while taking information and promotional actions and building an image. To this end, an interview with one of the leaders in the number of organic and traditional products in the cheese making industry was conducted. Based on that interview, it follows that products are promoted in a variety of different ways, whereas major barriers, but also challenges, include effective communication and ability to reach the consumer.
\end{abstract}

Keywords: traditional product, organic product, management, quality, marketing, building an image, promotion, public relations.

\section{INTRODUCTION}

Traditional and organic products are a real asset of a region and also one of priorities of the EU's agricultural policy and the rural development policy. The production of highquality products (both traditional and organic ones) contributes to the growth of local businesses through the use of local potential.

In Poland, many actions are undertaken with a view to supporting the agri-food industry. Moreover, many initiatives are launched, which are designed not only to support and popularise this sector, but also cherish culinary traditions, inter alia, by creating clusters, trails (e.g. culinary, cultural, wine trails), carrying out local, national or international projects (financed by the EU funds etc.).

In Europe, that trend has been seen for a much longer period of time. Consumers consciously look for high-quality products, which are made to traditional recipes and by traditional methods. In other countries, local products can be obtained directly from a maker or purchased in a nearby shop, chain stores, markets or even at petrol stations (i.e. in Austria).

Developing the production of traditional and regional products also increases the economic importance of regions, makes them more attractive to tourists and supports

\footnotetext{
${ }^{1}$ Ewelina Nycz, MA, Department of Marketing, The Faculty of Management, Rzeszów University of Technology, Aleja Powstańców Warszawy 12, 35-959 Rzeszów; e-mail: ewelina.nycz@gmail. com. ORCID: 0000-0002-4363-9205.
} 
activities contributing to the conservation of cultural heritage and the protection of the environment (Krupa, 2009).

A global trend towards returning to natural, simple foodstuffs provides an opportunity for Polish producers. At present, consumers are seeking high-quality products, which can be observed in shops (e.g. shelves containing dedicated organic food), yet this is still not that much compared with the number of mass-produced articles (Jęczmyk, 2015). Greater demand for high-quality foodstuffs has encouraged their growth.

The aim of this paper was to present and demonstrate how traditional and organic products are promoted on the example of products originating from Podkarpackie Province and to indicate barriers, challenges that must be overcome while taking information and promotional actions and building an image. An interview with one of the leaders in the number of organic and traditional products in the cheese making industry was conducted. Furthermore, the article contains information which is based on the author's own experience and professional collaboration in the field of promotion and development of products, as well as uses materials derived from various sources, including from the Internet.

\section{TRADITIONAL AND ORGANIC PRODUCTS}

Traditional and organic food comprises a small percentage of products in the market compared to mass-produced articles. The production of high-quality products requires a lot of time and work related to natural production, but also the procurement of proper raw materials. Products made in a given region (a raw material, climate) have a unique "flavour and aroma" which is unusual anywhere else and constitutes another distinctive characteristic of this group of products. Due to consumers' and producers' increased interest in traditional and organic products, the distinguishing feature of which is exceptional quality, it is worth paying attention to this market segment when travelling across Poland or abroad - each region can surprise, offering local food and original drinks.

\subsection{Traditional Products Included on List of Traditional Products}

The distinguishing features of a traditional product are a traditional production method that corresponds with cultural heritage and the quality of product, both of which translate into consumers' confidence. In the European Union, it is a particular national treasure and cultural heritage, as well as an important component of the culinary and tourist promotion of both individual regions and the entire country (Gulbicka, 2014).

As provided for in Article 3 of the Regulation (EU) No 1151/2012 of the European Parliament and of the Council of 21 November 2012 on quality schemes for agricultural products and foodstuffs (Rozporządzenie Parlamentu Europejskiego, 2012, art. 3) a word "traditional" means proven usage on the domestic market for a period that allows transmission between generations; this period is to be at least 30 years. Several years ago, makers were obliged to prove a twenty-five-year period of manufacture.

The Polish Minister of Agriculture and Rural Development has been responsible, since 2005, for compiling the List of Traditional Products at a national level pursuant to the Act on Registration and Protection of Names and Symbols of Agricultural Products, Foodstuffs and Traditional Products of 17 December 2004 (Ustawa, 2004, rozdz. 8, art. 47-56.). This list is also used to prepare producers for the registration of product names it contains at the EU level. In total, the list comprises 1,983 traditional products (September 2020) - table 1 . 
Traditional and organic products...

Table 1. Products Included on List of Traditional Products Broken Down into Provinces

\begin{tabular}{|c|c|c|}
\hline Item & Province & Number of Products \\
\hline 1. & Lower Silesia Province & 52 \\
\hline 2. & Kujawy-Pomerania Province & 92 \\
\hline 3. & Lublin Province & 223 \\
\hline 4. & Lubuskie Province & 151 \\
\hline 5. & Łódź Province & 224 \\
\hline 6. & Małopolska Province & 154 \\
\hline 7. & Mazovia Province & 68 \\
\hline 8. & Opole Province & 246 \\
\hline 9. & Podkarpackie Province & 74 \\
\hline 10. & Podlasie Province & 179 \\
\hline 11. & Pomerania Province & 145 \\
\hline 12. & Silesia Province & 94 \\
\hline 13. & Świętokrzyskie Province & 46 \\
\hline 14. & Warmia-Mazuria Province & 98 \\
\hline 15. & Wielkopolska Province & 55 \\
\hline 16. & West Pomerania Province & $\mathbf{1 , 9 8 3}$ \\
\hline & Total & h \\
\hline
\end{tabular}

Source: Own elaboration based on List of Traditional Products https://www.gov.pl/ web/rolnictwo/lista-produktow-tradycyjnych12.

When one considers the type of an agricultural product, foodstuff or a spirit drink on the List of Traditional Products in Poland, it includes, but is not limited to, the following categories: fresh meat and meat products $(22 \%)$, prepared meals and dishes $(21 \%)$, baker's wares and confectionery (18\%), beverages (11\%), nuts, seeds, cereals, fruit and vegetables $(9 \%)$, cheeses and other dairy products $(6 \%)$, honeys $(5 \%)$, oils and fats (butter, margarine, etc.) $-3 \%$, and other. Individual types of product, broken down into provinces, are listed in Table 2.

Table 2. Type of Agricultural Product, Foodstuff or Spirit Drink Included on List of Traditional Products in Poland

\begin{tabular}{|c|c|c|c|c|c|c|c|c|c|c|c|}
\hline Province & $\begin{array}{c}\text { Pre- } \\
\text { pared } \\
\text { meals } \\
\text { and } \\
\text { dishes }\end{array}$ & $\begin{array}{l}\text { Other } \\
\text { pro- } \\
\text { ducts }\end{array}$ & $\begin{array}{c}\text { Fresh } \\
\text { meat } \\
\text { and } \\
\text { meat } \\
\text { pro- } \\
\text { ducts }\end{array}$ & Honeys & $\begin{array}{l}\text { Beverages } \\
\text { (alcoholic } \\
\text { and } \\
\text { alcohol- } \\
\text { free) }\end{array}$ & $\begin{array}{c}\text { Oils } \\
\text { and } \\
\text { fats } \\
\text { (butter, } \\
\text { marga- } \\
\text { rine, } \\
\text { etc.) }\end{array}$ & $\begin{array}{l}\text { Nuts, } \\
\text { seeds, } \\
\text { cereals, } \\
\text { fruit and } \\
\text { vegeta- } \\
\text { bles } \\
\text { (pro- } \\
\text { cessed } \\
\text { and } \\
\text { unpro- } \\
\text { cessed) }\end{array}$ & $\begin{array}{c}\text { Fishery } \\
\text { pro- } \\
\text { ducts, } \\
\text { inclu- } \\
\text { ding fish }\end{array}$ & $\begin{array}{c}\text { Cheeses } \\
\text { and other } \\
\text { dairy } \\
\text { products }\end{array}$ & $\begin{array}{c}\text { Baker's } \\
\text { wares } \\
\text { and } \\
\text { confe- } \\
\text { ctionery }\end{array}$ & Total \\
\hline $\begin{array}{c}\text { Lower } \\
\text { Silesia } \\
\text { Province }\end{array}$ & 8 & 0 & 11 & 6 & 6 & 1 & 4 & 3 & 4 & 9 & 52 \\
\hline $\begin{array}{l}\text { Kujawy- } \\
\text {-Pomerania } \\
\text { Province }\end{array}$ & 27 & 6 & 8 & 1 & 14 & 2 & 9 & 1 & 6 & 18 & 92 \\
\hline
\end{tabular}


Table 2 (cont.). Type of Agricultural Product, Foodstuff or Spirit Drink Included on List of Traditional Products in Poland

\begin{tabular}{|c|c|c|c|c|c|c|c|c|c|c|c|}
\hline Province & $\begin{array}{c}\text { Pre- } \\
\text { pared } \\
\text { meals } \\
\text { and } \\
\text { dishes }\end{array}$ & $\begin{array}{l}\text { Other } \\
\text { pro- } \\
\text { ducts }\end{array}$ & $\begin{array}{l}\text { Fresh } \\
\text { meat } \\
\text { and } \\
\text { meat } \\
\text { pro- } \\
\text { ducts }\end{array}$ & Honeys & $\begin{array}{l}\text { Beverages } \\
\text { (alcoholic } \\
\text { and } \\
\text { alcohol- } \\
\text { free) }\end{array}$ & \begin{tabular}{|c|} 
Oils \\
and \\
fats \\
(butter, \\
marga- \\
rine, \\
etc.)
\end{tabular} & $\begin{array}{l}\text { Nuts, } \\
\text { seeds, } \\
\text { cereals, } \\
\text { fruit and } \\
\text { vegeta- } \\
\text { bles } \\
\text { (pro- } \\
\text { cessed } \\
\text { and } \\
\text { unpro- } \\
\text { cessed) }\end{array}$ & $\begin{array}{c}\text { Fishery } \\
\text { pro- } \\
\text { ducts, } \\
\text { inclu- } \\
\text { ding fish }\end{array}$ & $\begin{array}{c}\text { Cheeses } \\
\text { and other } \\
\text { dairy } \\
\text { products }\end{array}$ & $\begin{array}{l}\text { Baker's } \\
\text { wares } \\
\text { and } \\
\text { confe- } \\
\text { ctionery }\end{array}$ & Total \\
\hline $\begin{array}{l}\text { Lublin } \\
\text { Province }\end{array}$ & 49 & 3 & 29 & 10 & 37 & 8 & 20 & 6 & 11 & 50 & 223 \\
\hline $\begin{array}{l}\text { Lubuskie } \\
\text { Province }\end{array}$ & 8 & 1 & 19 & 7 & 14 & 2 & 8 & 4 & 6 & 13 & 82 \\
\hline $\begin{array}{c}\text { Łódź } \\
\text { Province }\end{array}$ & 25 & 0 & 39 & 5 & 18 & 3 & 20 & 2 & 8 & 31 & 151 \\
\hline $\begin{array}{l}\text { Małopolska } \\
\text { Province }\end{array}$ & 43 & 5 & 78 & 8 & 18 & 1 & 15 & 0 & 13 & 43 & 224 \\
\hline $\begin{array}{l}\text { Mazovia } \\
\text { Province }\end{array}$ & 34 & 5 & 39 & 9 & 24 & 5 & 13 & 5 & 5 & 15 & 154 \\
\hline $\begin{array}{c}\text { Opole } \\
\text { Province }\end{array}$ & 18 & 4 & 10 & 3 & 3 & 3 & 8 & 2 & 3 & 14 & 68 \\
\hline $\begin{array}{c}\text { Podkarpackie } \\
\text { Province }\end{array}$ & 49 & 1 & 80 & 6 & 16 & 4 & 11 & 3 & 25 & 51 & 246 \\
\hline $\begin{array}{l}\text { Podlasie } \\
\text { Province } \\
\end{array}$ & 11 & 3 & 12 & 3 & 7 & 3 & 7 & 2 & 11 & 15 & 74 \\
\hline $\begin{array}{l}\text { Pomerania } \\
\text { Province }\end{array}$ & 52 & 5 & 27 & 3 & 20 & 5 & 16 & 17 & 4 & 30 & 179 \\
\hline $\begin{array}{c}\text { Silesia } \\
\text { Province }\end{array}$ & 55 & 1 & 13 & 5 & 7 & 2 & 12 & 5 & 12 & 33 & 145 \\
\hline $\begin{array}{l}\text { Święto- } \\
\text { krzyskie } \\
\text { Province }\end{array}$ & 8 & 2 & 25 & 7 & 4 & 4 & 17 & 6 & 4 & 17 & 94 \\
\hline $\begin{array}{l}\text { Warmia- } \\
\text {-Mazuria } \\
\text { Province }\end{array}$ & 10 & 0 & 15 & 5 & 3 & 0 & 2 & 1 & 3 & 7 & 46 \\
\hline $\begin{array}{c}\text { Wielkopolska } \\
\text { Province }\end{array}$ & 24 & 2 & 33 & 2 & 10 & 6 & 8 & 1 & 6 & 6 & 98 \\
\hline $\begin{array}{c}\text { West } \\
\text { Pomerania } \\
\text { Province }\end{array}$ & 4 & 1 & 4 & 12 & 9 & 1 & 7 & 6 & 1 & 10 & 55 \\
\hline Total & 425 & 39 & 442 & 92 & 210 & 50 & 177 & 64 & 122 & 362 & 1,983 \\
\hline
\end{tabular}

Source: Own elaboration based on List of Traditional Products https://www.gov.pl/web/ rolnictwo/lista-produktow-tradycyjnych 12 .

On a closer examination of the List of Traditional Products, one can point out the leaders as regards the number of traditional products. The region with the greatest number of products registered on the LTP is Podkarpackie Province, which accounts for $12.4 \%$, followed by Małopolska Province (11.3\%) and Lublin Province (11.24\%). 
Table 3. Ranking of Three Provinces with Greatest Number of Registered Products Broken Down into Type of Agricultural Product, Foodstuff or Spirit Drink Included on List of Traditional Products

\begin{tabular}{|l|c|c|c|}
\hline $\begin{array}{c}\text { Type of Agricultural Product, Foodstuff } \\
\text { or Spirit Drink }\end{array}$ & $\begin{array}{c}\text { Małopolska } \\
\text { Province }\end{array}$ & $\begin{array}{c}\text { Lublin } \\
\text { Province }\end{array}$ & $\begin{array}{c}\text { Podkarpackie } \\
\text { Province }\end{array}$ \\
\hline Total - 1,983 & $\mathbf{2 2 4}$ & $\mathbf{2 2 3}$ & $\mathbf{2 4 6}$ \\
\hline Prepared meals and dishes & 43 & $\mathbf{4 9}$ & $\mathbf{4 9}$ \\
\hline Other products & 5 & 3 & 1 \\
\hline Fresh meat and meat products & $\mathbf{7 8}$ & 29 & $\mathbf{8 0}$ \\
\hline Honeys & 8 & $\mathbf{1 0}$ & 6 \\
\hline Beverages (alcoholic and alcohol-free) & 18 & $\mathbf{3 7}$ & 16 \\
\hline Oils and fats (butter, margarine, etc.) & 1 & $\mathbf{8}$ & 4 \\
\hline $\begin{array}{l}\text { Nuts, seeds, cereals, fruit and vegetables } \\
\text { (processed and unprocessed) }\end{array}$ & 15 & $\mathbf{2 0}$ & 11 \\
\hline Fishery products, including fish & 0 & $\mathbf{6}$ & 3 \\
\hline Cheeses and other dairy products & $\mathbf{1 3}$ & 11 & $\mathbf{2 5}$ \\
\hline Baker's wares and confectionery & $\mathbf{4 3}$ & $\mathbf{5 0}$ & $\mathbf{5 1}$ \\
\hline Total & $\mathbf{2 2 4}$ & $\mathbf{2 2 3}$ & $\mathbf{2 4 6}$ \\
\hline
\end{tabular}

Source: Own elaboration based on https://www.gov.pl/web/rolnictwo/lista-produktowtradycyjnych 12 .

The List of Traditional Products from Podkarpackie Province includes kietbasa pótsucha z Górna (semi-dried sausage from Górno), proziaki (flour-based rolls with added sodium bicarbonate), chrupaczki (cake made from wholemeal flour, yeasts, eggs, milk pork fat and sugar) or śliwowica krzeszowska (plum vodka from Krzeszów) and many more. Traditional products of Małopolska Province include oscypek (smoked ewe's milk cheese made in the Tatra Mountains), bryndza podhalańska (ewes' milk cheese of Podhale region), karp zatorski (carp of Zator), whereas those originating from Lublin Province are krupnik pszczelowolski (spirit with honey and spices), lubelski forszmak (goulash served in a bread bowl with pickled cucumbers) and gruszka suszona kraśnicka (dried pear of Kraśnik) etc.

\subsection{Organic Products}

An organic product is the outcome of organic farming, for which natural qualities of the environment in which it is produced are preserved. This also includes a sustainable agricultural system in which attention is given both to the environment and the welfare of animals. It comprises all stages of the food supply chain: delivery of raw materials, processing, storage, transport, distribution, retail services and product marking (labelling). Organic farming is governed by the provisions of the Council Regulation (EC) No 834/2007 of 28 June 2007 on organic production and labelling of organic products and repealing Regulation (EEC) No. 2092/91(Rozporządzenie, 2007).

Organic farming is based on natural processes taking place within a farm and simple production methods. In order for a product to become a fully organic product, the maker has to meet specific production and quality requirements, which is confirmed by a certification and control process (carried out by specialist institutions). 
Cardinal importance is attached to the recognisability of organic products, a so-called small green leaf (an EU's organic logo), which is a guarantee that a product has been manufactured in accordance with the European Union's law relating to organic production.

In Poland, at the end of 2019, there were 20,200 entities that carried out operations within the framework of an official organic farming system (a $2 \%$ decline compared to 2018). According to Nielsen's report, organic product sales in Poland in 2019 stood at approx. PLN 620m (Rynek żywności eko, 2020). From the beginning of 2020, organic product sales have risen by more than $20 \%$, which was driven by the pandemic and a desire for healthier nutrition over that time (Produkty BIO, 2020).

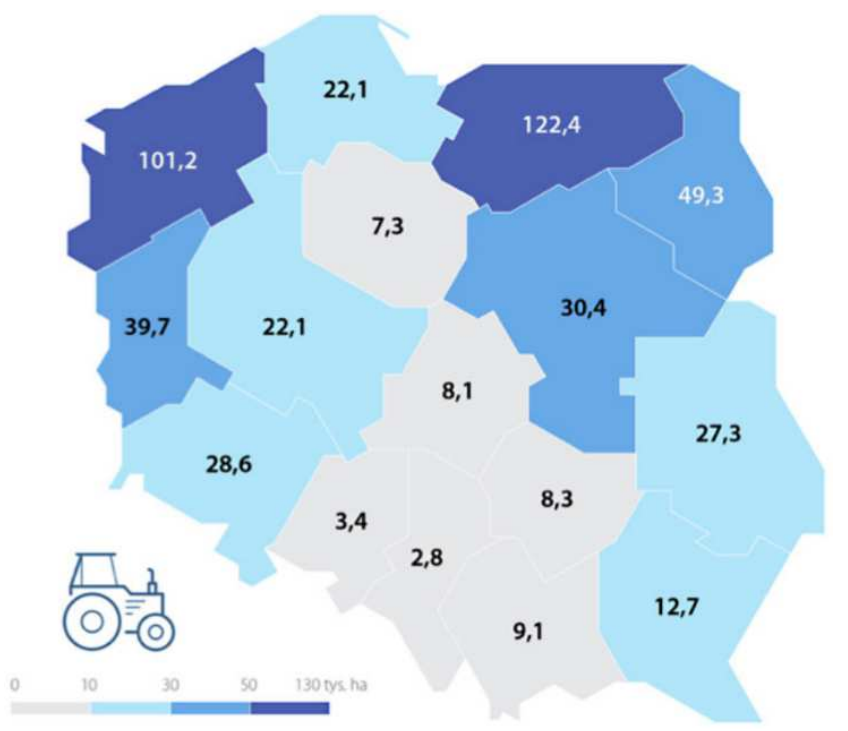

Fig. 1. Area of Organic Farmland in Poland in 2018 Broken Down by Provinces

Source: https://swiatrolnika.info/uprawy-ekologiczne-w-polsce.

Having considered multiple regulations, restrictions on organic production, it is clear (Rynek żywności eko, 2020) that throughout four years the number of organic producers in Poland has declined by 19\%, from approx. 25,500 to 20,500 in 2018, whereas the area of organic farmland fell by approx. $25 \%$ to approx. 485,000 hectares. As regards processing, this production is definitely on the rise, however, as far as organic farmland is concerned, one can observe a downward trend, which is completely contrary to what is seen in EU countries.

\section{TRADITIONAL AND ORGANIC PRODUCTS IN "FIGA" FAMILY-OWNED ORGANIC FARM}

Podkarpackie Province is the leader as regards the number of traditional products (246). Clean environment of the region, dedication to preserving tradition, the availability of many family-owned businesses scattered across the entire province and a passion for natural potential which can be used are real assets. 
Podkarpackie Province has seen an increase in the production of high-quality - both organic and traditional - food. Such a growing trend is also manifested through greater interest in new products of the countryside, and consequently, attention given to top-quality life (Strategia, 2020).

A good example of a producer that has managed to use its potential: the nature, green areas, clean environment of the region, family values - and to combine it with an interesting lifestyle and way of living, in line with the Slow Food philosophy, is Rodzinne gospodarstwo ekologiczne „FIGA” sc. Waldemar i Tomasz Maziejuk, a family-owned organic farm from Mszana. Products available on the farm's offer are 100\% organic (33 products), eight of which are included on the List of Traditional Products - 24.24\% (type of agricultural product, foodstuff or spirit drink, see the list: cheeses and other dairy products, oils and fats (butter, margarine, etc.).

The farm is located in Mszana, Krosno District, Dukla Commune (Przełęcz Dukielska, The Dukla Pass) and covers an area of 113 hectares (meadows and pastures). It is situated in a place which has perfect natural conditions - an environment conducive to running a farm engaged precisely in cattle and goat rearing and breeding (Beskid Niski, The Low Beskids). Ultimately, this translates into flavour and health-enhancing characteristics of products made in this region (Murawski, Kaczor, 2011).

This micro enterprise is owned by Waldemar Maziejuk, the father, and Tomasz Maziejuk, his son. The business is run by members of the family, and currently the third generation is also involved in it (Waldemar - the father, Tomasz and Wawrzyniec - his sons, Albert - Waldemar's grandson and Tomasz's son). This is an example of a family-owned firm from Podkarpackie Province, where approx. 33\% businesses are operated by families. In Poland family-owned firms account for 33.9\% (Uwarunkowania rozwoju, 2018).

The principal business of the farm is goat and cattle breeding (400 goats and 25 cows) and goat's milk processing. The farm specialises in the traditional processing of unpasteurized milk.

The farm's production includes 33 organic products: 23 goat's and 11 cow's dairy produces, i.e. cottage cheeses, rennet cheeses (bundz and bryndza), ripened cheeses, farmer's cheeses and Vallachai cheeses (ser wotoski), curd cheeses, home butter, which hold a certificate of conformity confirming that organic production methods have been employed, issued by BioCert Małoplska, a certification body from Cracow. Eight of those products are included on the List of Traditional Products.

The traditional production process taking place on the farm stems from long-standing cheese making traditions, which date back to the 16th century. This is, inter alia, because of Vlachs - a nomadic tribe of shepherds from the mountains, which came in those days to Mszana through a pass in the Carpathians from the Balkans (Żychowski, Jucha, 2020). In Poland, cheese production has been known for several centuries, and cheese making traditions of Podkarpackie Province date from the 15th century (Serowarstwo, 2020). Milk has recently become a global product; in Podkarpackie Province, there are around 15 registered cheese makers (one of them is "FIGA" Organic Farm in Mszana, run by Maziejuk family, and LEDA-SER Leszek Jakimowicz in Wólka Krowicka).

Table no. 5 presents the full range of traditional and organic products. The Maziejuk's business does not make conventional products. Compared to the period from three years ago, it continues to manufacture the same products (both traditional and organic ones), but the product range has been expanded - new flavours have been added to the offer, i.e. goat's 
milk farmer's cheese with black cumin and fenugreek and a new product line for cow's milk produces has been launched.

The offer is very rarely altered so as to meet consumers' expectations. As far as traditional products are concerned, it is difficult to change anything in those products, since the maker has to follow specific production processes. Two products were made at the suggestion of customers, who for many years had urged to introduce them, namely, goat's milk farmer's cheese with black cumin and fenugreek.

Table 4. List of Traditional and Organic Products Made by "FIGA" Family-Owned Organic Farm

\begin{tabular}{|c|c|c|c|}
\hline Item & Products & $\begin{array}{l}\text { Traditional } \\
\text { Product }\end{array}$ & Organic Product \\
\hline 1 & Bio śmietana domowa (Bio cream) & & $\mathrm{x}$ \\
\hline 2 & $\begin{array}{l}\text { Bryndza kozia tradycyjna (Traditional goat } \\
\text { bryndza cheese) }\end{array}$ & $\mathrm{x}$ & $\mathrm{x}$ \\
\hline 3 & Bryndza temkowska (Lemk's bryndza cheese) & $\mathrm{x}$ & $\mathrm{x}$ \\
\hline 4 & $\begin{array}{l}\text { Bundz kozi - naturalny (Fresh goat cheese - } \\
\text { natural) }\end{array}$ & $\mathrm{x}$ & $\mathrm{x}$ \\
\hline 5 & $\begin{array}{l}\text { Bundz kozi - wędzony (Fresh goat cheese - } \\
\text { smoked) }\end{array}$ & $\mathrm{x}$ & $\mathrm{x}$ \\
\hline 6 & $\begin{array}{l}\text { Bundz temkowski naturalny (Lemk's fresh } \\
\text { cheese - natural) }\end{array}$ & $\mathrm{x}$ & $\mathrm{x}$ \\
\hline 7 & $\begin{array}{l}\text { Bundz temkowski wędzony (Lemk's fresh cheese } \\
\text { - smoked) }\end{array}$ & $\mathrm{x}$ & $\mathrm{x}$ \\
\hline 8 & Ekologiczne mleko kozie (Organic goat milk) & & $\mathrm{x}$ \\
\hline 9 & Ekologiczne mleko krowie (Organic milk) & & $\mathrm{x}$ \\
\hline 10 & Masto domowe (Home butter) & & $\mathrm{x}$ \\
\hline 11 & $\begin{array}{l}\text { Masto domowe klarowane (Home clarified } \\
\text { butter) }\end{array}$ & & $\mathrm{x}$ \\
\hline 12 & Masto kozie Bio (Goat butter bio) & & $\mathrm{x}$ \\
\hline 13 & Maślanka Bio (Bio buttermilk) & & $\mathrm{x}$ \\
\hline 14 & $\begin{array}{l}\text { Ser kozi farmerski dojrzewajacy (Farmer's goat } \\
\text { cheese - matured) }\end{array}$ & & $\mathrm{x}$ \\
\hline 15 & $\begin{array}{l}\text { Ser kozi farmerski naturalny (Farmer's goat } \\
\text { cheese - natural) }\end{array}$ & & $\mathrm{x}$ \\
\hline 16 & $\begin{array}{l}\text { Ser kozi farmerski z czarnuszka (Farmer's goat } \\
\text { cheese - black cumin) }\end{array}$ & & $\mathrm{x}$ \\
\hline 17 & $\begin{array}{l}\text { Ser kozi farmerski z cząbrem (Farmer's goat } \\
\text { cheese - savory) }\end{array}$ & & $\mathrm{x}$ \\
\hline 18 & $\begin{array}{l}\text { Ser kozi farmerski z jałowcem (Farmer's goat } \\
\text { cheese - juniper) }\end{array}$ & & $\mathrm{x}$ \\
\hline 19 & $\begin{array}{l}\text { Ser kozi farmerski z kozieradka (Farmer's goat } \\
\text { cheese - fenugreek) }\end{array}$ & & $\mathrm{x}$ \\
\hline 20 & $\begin{array}{l}\text { Ser kozi farmerski z papryka i chili (Farmer's } \\
\text { goat cheese - paprika \& chilli) }\end{array}$ & & $\mathrm{x}$ \\
\hline 21 & $\begin{array}{l}\text { Ser kozi farmerski z pieprzem (Farmer's goat } \\
\text { cheese - pepper) }\end{array}$ & & $\mathrm{x}$ \\
\hline
\end{tabular}


Table 4 (cont.). List of Traditional and Organic Products Made by "FIGA" Family-Owned Organic Farm

\begin{tabular}{|c|c|c|c|}
\hline Item & Products & $\begin{array}{l}\text { Traditional } \\
\text { Product }\end{array}$ & Organic Product \\
\hline 22 & $\begin{array}{l}\text { Ser kozi wotoski naturalny (Vallachai goat } \\
\text { cheese - natural) }\end{array}$ & $\mathrm{x}$ & $\mathrm{x}$ \\
\hline 23 & $\begin{array}{l}\text { Ser kozi wotoski wędzony (Vallachai goat cheese } \\
\text { - smoked) }\end{array}$ & $\mathrm{x}$ & $\mathrm{x}$ \\
\hline 24 & $\begin{array}{l}\text { Ser temkowski naturalny (Lemk's cheese - } \\
\text { natural) }\end{array}$ & & $\mathrm{x}$ \\
\hline 25 & $\begin{array}{l}\text { Ser temkowski wędzony (Lemk's cheese - } \\
\text { smoked) }\end{array}$ & & $\mathrm{x}$ \\
\hline 26 & $\begin{array}{l}\text { Ser pasterski dojrzewajacy (Sheperd's cheese - } \\
\text { maturated) }\end{array}$ & & $\mathrm{x}$ \\
\hline 27 & $\begin{array}{l}\text { Ser pasterski naturalny (Sheperd's cheese - } \\
\text { natural) }\end{array}$ & & $\mathrm{x}$ \\
\hline 28 & $\begin{array}{l}\text { Ser pasterski wędzony (Sheperd's cheese - } \\
\text { smoked) }\end{array}$ & & $\mathrm{x}$ \\
\hline 29 & Twarożek kozi naturalny (Goat cottage - natural) & & $\mathrm{x}$ \\
\hline 30 & Twarożek kozi smakowy (Goat cottage - herby) & & $\mathrm{x}$ \\
\hline 31 & $\begin{array}{l}\text { Twarożek kozi z papryka i chili (Goat cottage - } \\
\text { paprika\&chilli) }\end{array}$ & & $\mathrm{x}$ \\
\hline 32 & $\begin{array}{l}\text { Twarożek zbierany naturalny (Cottage cheese - } \\
\text { natural) }\end{array}$ & & $\mathrm{x}$ \\
\hline 33 & $\begin{array}{l}\text { Twaróg zbierany z czabrem i czosnkiem (Cottage } \\
\text { cheese - savory \& garlic) }\end{array}$ & & $\mathrm{x}$ \\
\hline
\end{tabular}

Source: Own elaboration based on the List of Traditional Products https://www.gov.pl/ web/rolnictwo/lista-produktow-tradycyjnych12 and Certificate of Conformity https://www. serymaziejuk.pl/.

The products made by this family-owned business are highly recognisable in big cities, i.e. Cracow and Warsaw. However, as regards Podkarpackie Province, only now is the brand being built, which is due to collaboration with a local chain store (the availability of products on shop shelves). The products and the brand are, first of all, recognised in the country by people (consumers) who are interested in organic food.

When asked about competition, the producer replies that they are an "original" farm with a niche product and are not interested in talking about competitors. Simultaneously, four distinctive features of the farm were highlighted:

- Family ties - family members are close to each other, the business has strong potential and its growth serves for the benefit of generations (currently the third generation is engaged to bring the success);

- Business on a local scale - animal breeding and rearing and product manufacture is located in a particular place (Mszana);

- Ecology and tradition - ecology is both the sense and essence of life (cultivation of land, animal breeding and rearing, production), whereas traditional products have been made since the 17 th century; 
- Uncomplicated production processes - the simplest production method, which enables the maker to manufacture as clean product as possible - so that the customer knows that it is the healthiest.

As regards the recognisability of marking attached to organic products from farms a so-called green leaf, today's consumers' awareness in this respect is greater than a few years ago. Therefore, marking has major importance and makes it possible to gain competitive advantage. This is entirely contrary to traditional products, which do not bear any marking on their labels - they only have a certificate. However, this fact does not translate into greater recognisability. When such marking appears on products, this means, first and foremost, that the maker may enjoy prestige (but on the other hand, they can also face a challenge). Also the customer, who is aware of how difficult it is to manufacture such products and include them on the list, finds the marking both prestigious and challenging. This proves strong need for promotion of such products.

The interview revealed that consumers are nowadays more aware of traditional and organic products compared to the period from 15 years ago, when products were certified for the first time - according to the maker. He emphasised that this observation stems from information and promotional activities being performed, such as promotional campaigns relating to the promotion of traditional and organic products, campaigns aimed at supporting Polish products and local makers, i.e. Buy Consciously - Polish Product (Kupuj Świadomie - Produkt Polski), which are organised, inter alia, by the Ministry of Agriculture and Rural Development, the National Centre for Support of Agriculture or other industry-related organisations. However, people are also more aware because they started to pay greater attention to what they eat, which is possible, among other things, due to useful applications installed on their mobile phones, i.e. Zdrowe Zakupy (Healthy Shopping) ${ }^{2}$ or Pola. Zabierz ja na zakupy (Pola. Take it for shopping) ${ }^{3}$.

It is noteworthy that Polish customers are very diversified (which depends on their awareness, affluence, lifestyle, but also individual preferences). Therefore as regards information and education, both customers and makers have much to do.

Nobody at the Maziejuk's business conducts any customer-satisfaction surveys or seeks any opinions, even though they consider doing so. They often receive information regarding positive reactions via email or through Messenger ${ }^{4}$. Feedback is given at trade fairs or during events, that is when face-to-face meetings are possible.

Products are sold not only in brick-and-mortar shops, located mainly in bigger cities, but also through the online shop www.serymaziejuk.pl (since March 2020) - however, 60\% of customers do the shopping by means of mobile phones. Moreover, the Maziejuk's business is involved in an initiative of the Subcarpathian Flavours Cluster (Klaster Podkarpackie Smaki), where products are sold through www.sklep.podkarpackiesmaki.pl and sales are made as part of a so-called initiative LokalnyRolnik.pl (local farmer) (cities: Wrocław, Cracow, Opole).

\footnotetext{
${ }^{2}$ Aplikacja Zdrowe Zakupy - aplikacja na telefon, która pozwala na otrzymanie informacji na temat produktu (składniki, dodatki, e-składniki, konserwanty, emulgatory, stabilizatory, alergeny) poprzez zeskanowanie kodu kreskowego (https://zdrowezakupy.org/).

3 Aplikacja Pola. Zabierz ją na zakupy - aplikacja na telefon, która pozwala na otrzymanie informacji na temat produktu i firmy (kapitał polski czy zagraniczny, produkcja, miejsca pracy), która go wyprodukowała poprzez zeskanowanie kodu kreskowego (https://www.pola-app.pl/).

${ }^{4}$ Messenger - komunikator internetowy, który umożliwia rozmowy tekstowe oraz głosowe, a także przesyłanie zdjęć, plików, filmów (https://www.messenger.com/).
} 
The farm does not carry out any operations nor make any sales abroad, but receives various foreign visitors, who purchase products on the site and explore the entire area. The Maziejuk's business participates in many trade fairs, for instance, in one of the world's largest fair for organic food called BIOFACH (for ten years), Foodex Japan fair in Tokyo, Summer Fancy Food Show in the USA or the Polish Food Festival in Singapore. These activities have not translated into product sales yet, however, they constitute an essential activity designed to explore other markets and promotions. This is proved by the fact that trade fairs have rather become information exchange centres and marketing activity instruments (Gębarowski, 2006).

As the maker claims, in recent years the promotion of high-quality products and the way of reaching the customer have changed dramatically. The owners are aware that both marketing and Public Relations are the key to a successful family business. The Maziejuk's farm promotes itself on Facebook and Instagram (free-of-charge posts), at trade fairs (within the region, country, abroad), but what must be given considerable importance in the case of a promotion strategy is human contact and contact with the product. Responsibility for promotional activities rests with one of the brothers (Wawrzyniec), who has a vision and pursues a strategy for information and promotional activities. The strategy of Maziejuk's business is designed to show "genuineness".

As for marketing activities, a tool that is used the most often is the Internet: the farm's website www.serymaziejuk.pl, its profile on Facebook www.facebook.com/sery.maziejuk, Instagram www.instagram.com/sery.kozie.maziejuk, participation in trade fairs and interpersonal contact. The Maziejuk's firm has recently mounted an advertising campaign in local newspapers (with a circulation of 70,000 covering four districts), but this did not bring any effects in terms of sales, which was - according to the maker - due to a multitude of advertisements. There are plans to launch a billboard campaign and rent a car with an advertising trailer (a mobile ad) to promote the Maziejuk's firm in Podkarpackie Province.

The farm is involved in Public Relations, in which the main focus is given to the customer, the good reputation of products and the business itself. The Maziejuk's business co-operated with Public Relations agencies, although for the past several years they have been carrying out actions and strategies on their own. As it has been emphasised by the maker, it plans to collaborate with agencies, which results from changes in the customer's profile, their convenience, the simplification of purchasing decision. The greatest challenge for the farm is to ensure effective communication and reach the consumer in an efficient way.

As regards managing an enterprise which has such a difficult product (shelf life, products which are not considered to be the basic necessities, price, organic production, organic raw materials, e.g. spices etc.), the maintenance of a business offering high-quality products and being stable on the market - constitutes a challenge.

The farm works with many institutions and organisations, i.e. the Polish Association of Processors and Producers of Organic Products "Polish Ecology", the Association for the Development and Promotion of Podkarpacie "Pro Carpathia", the Polish Chamber of Regional and Local Product, the Subcarpathian Flavours Cluster and the Organic Food Polish Ecology Cluster, as as well as with local governments, such as the Marshal's Office of Podkarpackie Province.

The farm also co-operates with the cultural tourism industry, inter alia, travel agencies, tour operators, as well as with the hotel and restaurant industry (hotels and restaurants as part of a local product card), and through cultural trails - products for tourists, i.e. the 
Wallachian Culture Trail, the Subcarpathian Flavours Culinary Trail, or by participating in initiatives related to food tourism. In 2019, the farm was visited by approximately 450 people.

\section{SUMMARY}

Traditional and organic products are distinguishing marks of a region, reflect a long-established tradition and cultural heritage, as well as show potential for the growth of local businesses.

The aim of this paper was to present and demonstrate how traditional and organic products are promoted on the example of products originating from Podkarpackie Province and to indicate barriers, challenges that must be overcome while taking information and promotional actions and building an image.

Based on the interview, it follows that products are promoted in various ways, e.g. through the Internet, by participation in trade fairs in Poland and abroad, as well as face-toface contact and so-called buzz marketing. Major barriers, but also challenges, include effective communication and reaching the consumer in an efficient manner. Traditional and organic products require specific marketing activities and Public Relations, also in order to build an image.

As the owners emphasise, to manage such a broad product range (33 organic products, including 8 traditional ones) and maintain high quality of products - it is quite a challenge. According to the maker, the industry needs support with regard to fast-evolving channels of promotion (participating in trainings, collaborating with agencies, following prevailing market trends). Greater and greater importance is attached to collaboration with the cultural tourism and culinary tourism industry - with a view to preparing a common offer (mapping places as attractions, one of travel destinations) - as well as to promotion and sales resulting from that collaboration. There is also a need for greater co-operation with the hotel and restaurant industry (sales of local products, e.g. local cheeses served for breakfasts), caseby-case co-operation with local governments (surveys, specific solutions, discussions) to enable the makers of high-quality products and the entire industry to adapt appropriate actions - a campaign (for micro-, small and medium-sized entrepreneurs).

Furthermore, one has to recognise immense significance that is attached to building the potential of respective regions having a rich abundance of traditional and organic products. The popularisation of these products is extremely relevant not only to local makers, but also to the entrepreneurship of respective provinces and to the growth of the Polish agriculture on the international scene.

\section{REFERENCES}

Gębarowski, M. (2006). Przeobrażenia funkcjonalne targów a rozwój Internetu. Studia i Prace Kolegium Zarządzania i Finansów. Zesz. Nauk., 70. Warszawa: SGH.

Główny Urząd Statystyczny. Uwarunkowania rozwoju przedsiębiorczości w sektorze MŚP, Warszawa 2018 [Access: 1.09.2020]. Access on the internet: https://stat.gov.pl/statystykieksperymentalne/badania-i-rozwoj-innowacyjnosc-spoleczenstwo-informacyjne/ uwarunkowania-rozwoju-przedsiebiorczosci-w-sektorze-msp, 1,1.html.

Gulbicka, B. (2014). Żywność tradycyjna i regionalna w Polsce, nr 116. Warszawa: Instytut Ekonomiki Rolnictwa i Gospodarki Żywnościowej - Państwowy Instytut Badawczy. 
http://potrawyregionalne.pl/270,9554,SEROWARSTWO_NA_PODKARPACIU .htm [Access: 1.09.2020].

https://swiatrolnika.info/uprawy-ekologiczne-w-polsce [Access: 9.10.2020]. https://www.gov.pl/web/rolnictwo/lista-produktow-tradycyjnych12 [Access: 1.09.2020]. https://www.messenger.com/ [Access: 1.10.2020]. https://www.pola-app.pl/ [Access: 1.10.2020]. https://www.serymaziejuk.pl/ [Access: 1.09.2020]. https://zdrowezakupy.org/ [Access: 1.10.2020].

Jęczmyk, A. (2015). Tradycyjne i regionalne produkty żywnościowe jako element rozwoju gospodarstw agroturystycznych. Studia KPZK, nr 164. Warszawa: PAN.

Krupa, J. (2009). Żywność tradycyjna i regionalna elementem promocji turystycznej Podkarpacia [w:] Dolatowski, Z.J., Kołożyn-Krajewska, D., red., Rozwój turystyczny regionów a tradycyjna żywność. Częstochowa: Wydawnictwo Wyższej Szkoły Hotelarstwa i Turystyki.

Murawski, M., Kaczor, U. (2011). Chów owiec i kóz w wybranych gospodarstwach Beskidu Niskiego [w:] Wiadomości Zootechniczne, R. XLIX, 3, Kraków: Państwowy Instytut Badawczy. Produkty BIO zdrowo rosna, [Access: 9.10.2020]. Access on the internet: https://www. nielsen.com/pl/pl/insights/article/2020/produkty-bio-zdrowo-rosna/.

Rozporządzenie Parlamentu Europejskiego i Rady (UE) nr 1151/2012 z dnia 21 listopada 2012 r. w sprawie systemów jakości produktów rolnych i środków spożywczych [Access: 9.10.2020]. Access on the internet: https://eur-lex.europa.eu/legal-content/PL/TXT/?uri=CELEX\%3A 32012R1151.

Rozporządzenie Rady (WE) nr 834/2007 z dnia 28 czerwca 2007 r. w sprawie produkcji ekologicznej i znakowania produktów ekologicznych i uchylające rozporządzenie (EWG) nr 2092/91 [Access: 9.10.2020]. Access on the internet: https://eur-lex.europa.eu/ LexUriServ/LexUriServ.do?uri=OJ:L:2007:189:0001:0023:PL:PDF.

Rynek żywności eko - w Europie rośnie, w Polsce kurczy się [Access: 9.10.2020]. Access on the internet: https://www.wiadomoscihandlowe.pl/artykul/rynek-zywnosci-eko-w-europie-rosniew-polsce-kurczy-sie.

Strategia rozwoju województwa - Podkarpackie 2030 [Access: 29.09.2020]. Access on the internet: http://www.sejmik.podkarpackie.pl/attachments/article/3367/strategia\%20Rozwoju \%20Wojew\%C3\%B3dztwa\%20Podkarpackiego\%202030.pdf.

Ustawa z dnia 17 grudnia 2004 r. o rejestracji i ochronie nazw i oznaczeń produktów rolnych i środków spożywczych oraz o produktach tradycyjnych [Access: 9.10.2020]. Access on the internet: http://isap.sejm.gov.pl/isap.nsf/download.xsp/WDU20050100068/U/D20050068Lj. pdfRozdz. 8, art. 47-56.

Żychowski J., Jucha W. (2020). Zmiany ustrojowe i rozwój przedsiębiorczości jako czynniki wpływajace na strukturę pokrycia i użytkowania terenu na przykładzie zlewni Bełczy i Mszanki w Beskidzie Niskim. „Przedsiębiorczość - Edukacja”, t. 16, nr 1. Warszawa - Kraków: Zakład Przedsiębiorczości i Gospodarki Przestrzennej, Instytut Geografii, Uniwersytet Pedagogiczny im. Komisji Edukacji Narodowej w Krakowie.

DOI: $10.7862 /$ rz.2020.mmr.31

The text was submitted to the editorial office: November 2020.

The text was accepted for publication: December 2020. 
